\title{
Floristic findings in the Kabardino-Balkar Republic (Central Caucasus)
}

\author{
Elena Stepanyan, Victoria Chadaeva ${ }^{*}$, Nelli Tsepkova \\ Tembotov Institute of Ecology of Mountain Territories of Russian Academy of Science, 360051 Nalchik, Russia
}

\begin{abstract}
The article presents information on floristic findings in the Kabardino-Balkari Republic. As a result of expedition research in 2020-2021 and inventory studies in the Herbarium of the Tembotov Institute of Ecology of Mountain Territories RAS, we revealed nine species new to the Kabardino-Balkar Republic and new locations of ten vascular plants species. Species new to the region flora were Carex acuta, Genista angustifolia, Amorpha fruticosa, Ambrosia psilostachya, Mercurialis annua, Echinocystis lobata, Phlomis majkopensis, Cleistogenes squarrosa, Bidens frondosa. New locations of seven species were identified for the Balkarskiy floristic region. These were three native species (Carex flacca subsp. erythrostachys, C. songorica, Eriophorum latifolium) and four alien species (Oenothera biennis, Elsholtzia ciliata, Sigesbeckia orientalis, Bidens frondosa). Carex elongata, Genista angustifolia, Ambrosia psilostachya, Mercurialis annua, Cleistogenes squarrosa, Amaranthus albus and alien species Acer negundo were revealed for the Tsentralno-Elbrusskiy and Kabardinskiy floristic regions, respectively. We also found the alien species Amorpha fruticosa, Echinocystis lobata and rare steppe species Phlomis majkopensis, Glaucium corniculatum in the Tursko-Sunzhensky floristic region. We provided data on floristic findings indicating the coordinates of the locations, species habitat preferences, and distribution in the Caucasus according to earlier literary sources.
\end{abstract}

\section{Introduction}

The decrease in the biological diversity of flora because of habitat degradation is an urgent regional and global problem [1-4]. The main reasons for the disappearance of plant species in the Kabardino-Balkar Republic are excessively high stocking rates, recreational activities, and large-scale agricultural development of steppe areas. Species inventory is a necessary scientific approach for the effective conservation of plant resources.

The history of studying the flora of the KabardinoBalkar Republic is associated with the names of such famous researchers as I.A. Gyuldenshtedt, A.K. Meyyer, P.S. Pallas, N.Ya. Dinnik, G.I. Radde, N.A. Bush, E.A. Bush, E.V. Shiffers, A.A. Grossheim, Yu.I. Kos, A.L. Kharadze, S.S. Kharkevich, and A.L. Takhtajan, etc. Due to the research of these scientists and the research of their followers, the region flora includes 2338 species of wild vascular plants from 681 genera, 140 families [5]. Nevertheless, inventory studies to identify new species of regional flora, as well as new localities of rare plant species in the Kabardino-Balkar Republic had not yet been completed. In the process, not only expedition research is important, but also the inventory of herbarium collections. The herbarium collection of the Tembotov Institute of Ecology of Mountain Territories of Russian Academy of Science was founded in 1995 and updated annually since then. Currently, the herbarium collection contains about three thousand herbarium specimens of more than 1280 species of vascular plants from more than 490 genera belonging to 104 families.

We report on the findings of 19 native and alien species, including nine species new to the region flora, and new locations of ten vascular plant species. Below are the data on floristic records with the coordinates of locations, species habitat preferences, and distribution in the Caucasus according to earlier literary sources.

\section{Materials and methods}

\subsection{Study area}

Kabardino-Balkar Republic occupies the central part of the northern macroslope of the Greater Caucasus (between $42^{\circ} 54^{\prime}-44^{\circ} 01^{\prime} \mathrm{N}$ and $42^{\circ} 24^{\prime}-44^{\circ} 28^{\prime} \mathrm{E}$ ) (Figure $1)$. The area of the region is 12.5 thousand square kilometers. Xerophytization of landscapes and the absence of broad-leaved forests belt are features of the northwestern part of the region (Elbrusskiy variant of vertical zonation [6]). Its vertical zonation includes meadow steppes (forest-steppes), steppe meadows, and subalpine, alpine, subnival and nival belts. Mesophytization of landscapes and a belt of mountain broad-leaved forests characterize the southeastern part of the Kabardino-Balkar Republic (Terskiy variant of vertical zonation). 


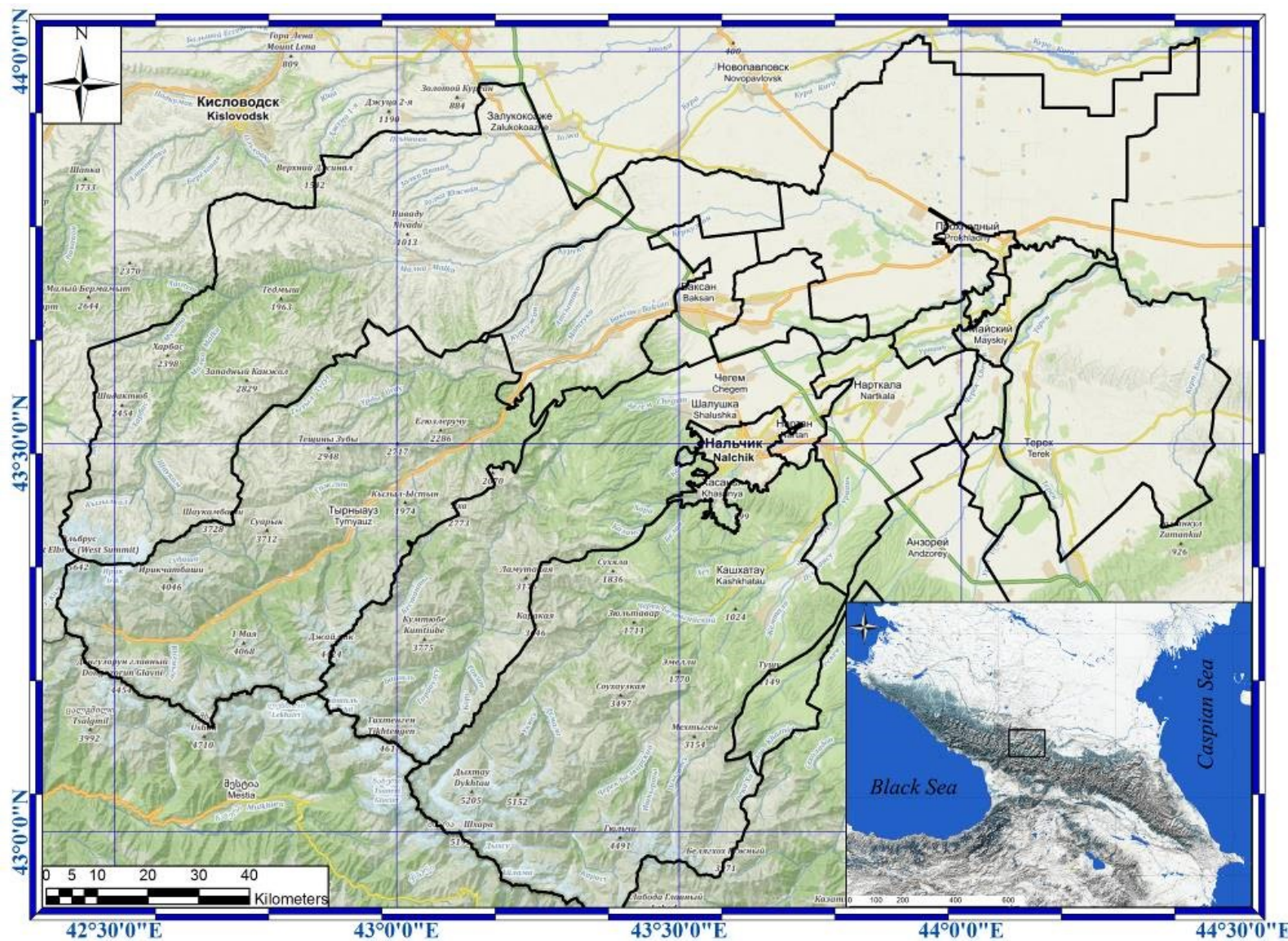

Fig. 1. Location and schematic map of the study area

The mountainous ground profile and arrival of western air masses from the Atlantic form a relatively cold and humid continental climate of mountain territories. The climate of the lowland areas is continental, relatively hot, and dry.

According to the detailed floristic zonation of the North Caucasus [7], which we use as the main one, the study area includes six floristic regions: TerskoSunzhenskiy, Kabardinskiy, Srednekumskiy, Leskenskiy, Tsentralno-Elbrusskiy, Balkarskiy. According to the less detailed floristic zonation of the Caucasus [8], the territory of the Kabardino-Balkar Republic includes only three floristic regions: Malkinskiy, Vostochnostavropolskiy, Verkhneterskiy.

\subsection{Data collection}

Expedition research was carried out in 2020-2021 in various forest and meadow ecosystems of the Kabardino-Balkar Republic from the steppes to the subnival belt. The authors of this article performed plant collections and species identification. Plant species nomenclature follows TPL (The Plant List) [9]. Geographical coordinates of new and rare plant species were recorded using a GPS navigator "Garmin GPSMAP 60CSx". Materials were transferred to the herbarium collection of the Tembotov Institute of Ecology of Mountain Territories RAS.
We also inventoried the herbarium collection of the Tembotov Institute of Ecology of Mountain Territories RAS, which updated annually for the past 20 years. The collection is in active use for historical and floral, botanical, geographical, geobotanical, and zoological research. Accordingly, a complete inventory of the herbarium collection is necessary, as well as the development of an electronic herbarium database.

\section{Results and discussion}

\subsection{New species in the flora of the Kabardino- Balkar Republic}

Amorpha fruticosa L. (Figure 2): $" 43^{\circ} 28^{\prime} 47.1^{\prime \prime} \mathrm{N}$, $44^{\circ} 02^{\prime} 57.6^{\prime \prime} \mathrm{E}$, Terskiy district, surroundings of the Aleksandrovskaya village, along the road, $253 \mathrm{~m}$ above sea level, 28 V 2021, V.A. Chadaeva, E.I. Stepanyan". North American deciduous shrubs usually growing on the sandy banks of ravines. The species widely introduced in Europe and Asia. It forms numerous selfseeding and root shoots in the invasion sites, quickly spreading over a vast territory. A.A. Grossheim [10] indicated the species as an ornamental plant only in culture. Location of Amorpha fruticosa belongs to the Tersko-Sunzhenskiy floristic region [7] or Verkhneterskiy floristic region [8] (Table. 0 ] 


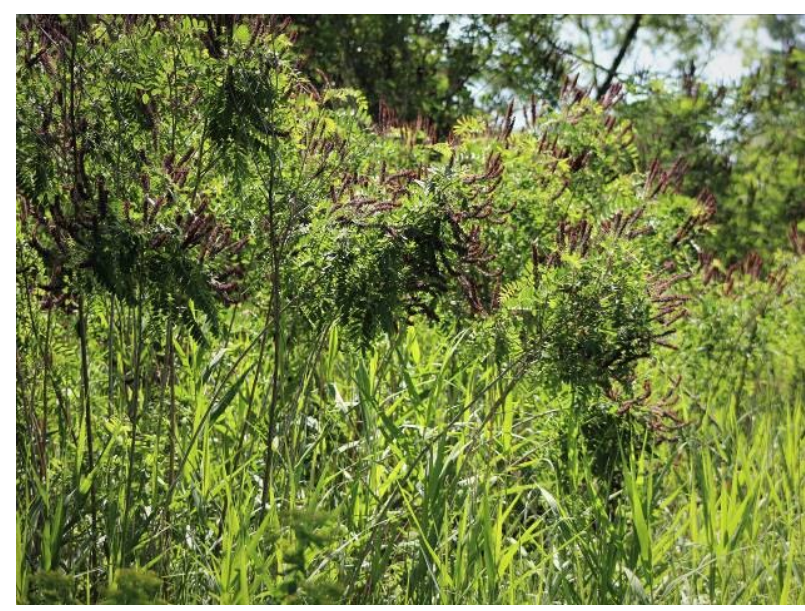

Fig. 2. Amorpha fruticosa in the Terskiy district
Ambrosia psilostachya DC. (Figure 3): "43⒉ $25.2^{\prime \prime} \mathrm{N} 43^{\circ} 37^{\prime} 45.0^{\prime \prime} \mathrm{E}$, Nalchik city, along the raileway, $500 \mathrm{~m}$ above sea level, 28 VII 2019, V.A. Chadaeva". - North American herbaceous perennial root-sprouting plant usually growing in open habitats with gravelly soils. The species is widely introduced in Australia, Central Asia, Europe. It forms numerous rhizomes in the soil, quickly spreading over the territory of invasion. Ambrosia psilostachya is qarantine plant, which pollen causes an allergic reaction. It successfully competes with native perennial plants and introduces into natural plant communities. The species was not previously indicated for the Kabardino-Balkar Republic. Location of the species belongs to the TsentralnoElbrusskiy floristic region [7] or Malkinskiy floristic region [8].

Table $\square$ Floristic regions of the species findings and distribution of the species in Kabardino-Balkar Republic according to earlier literary sources

\begin{tabular}{|c|c|c|c|c|}
\hline \multirow{3}{*}{ Species } & \multicolumn{4}{|c|}{ Floristic regions } \\
\hline & \multicolumn{2}{|c|}{ Floristic findings } & \multicolumn{2}{|c|}{ Literary sources } \\
\hline & $\begin{array}{c}\text { Floristic zonation of the } \\
\text { North Caucasus [7] }\end{array}$ & $\begin{array}{c}\text { Floristic zonation of } \\
\text { the Caucasus [8] }\end{array}$ & A.I. Galushko $[12,17,18]$ & $\begin{array}{c}\text { Caucasian flora conspectus } \\
{[13,15,16,19,20]}\end{array}$ \\
\hline Amorpha fruticosa & Tersko-Sunzhenskiy & Verkhneterskiy & - & - \\
\hline Ambrosia psilostachya & Tsentralno-Elbrusskiy & Malkinskiy & - & - \\
\hline Carex acuta & Balkarskiy & Malkinskiy & - & - \\
\hline Cleistogenes squarrosa & Tsentralno-Elbrusskiy & Malkinskiy & - & - \\
\hline Echinocystis lobata & Tersko-Sunzhenskiy & Verkhneterskiy & - & - \\
\hline Genista angustifolia & Tsentralno-Elbrusskiy & Malkinskiy & - & - \\
\hline Mercurialis annua & Tsentralno-Elbrusskiy & Malkinskiy & - & - \\
\hline Phlomis majkopensis & Tersko-Sunzhenskiy & Verkhneterskiy & - & - \\
\hline Acer negundo & Kabardinskiy & Malkinskiy & - & - \\
\hline Bidens frondosa & Balkarskiy & Malkinskiy & - & - \\
\hline Elsholtzia ciliata & Balkarskiy & Malkinskiy & - & - \\
\hline Carex songorica & Balkarskiy & Malkinskiy & - & Verkhneterskiy \\
\hline Eriophorum latifolium & Balkarskiy & Malkinskiy & - & Verkhneterskiy \\
\hline Oenothera biennis & Balkarskiy & Malkinskiy & $\begin{array}{c}\text { Leskenskiy, Kabardinskiy, } \\
\text { Tersko-Sunzhenskiy }\end{array}$ & - \\
\hline $\begin{array}{l}\text { Carex flacca subsp. } \\
\text { erythrostachys }\end{array}$ & Balkarskiy & Malkinskiy & Leskenskiy & $\begin{array}{c}\text { Central Caucasus (without } \\
\text { georeferencing) }\end{array}$ \\
\hline Carex elongata & Tsentralno-Elbrusskiy & Malkinskiy & Balkarskiy & Verkhneterskiy \\
\hline Glaucium corniculatum & Tersko-Sunzhenskiy & Verkhneterskiy & $\begin{array}{c}\text { Balkarskiy, Leskenskiy, } \\
\text { Tsentralno-Elbrusskiy }\end{array}$ & $\begin{array}{c}\text { Central Caucasus (without } \\
\text { georeferencing) }\end{array}$ \\
\hline Sigesbeckia orientalis & Balkarskiy & Malkinskiy & Leskenskiy & Malkinskiy, Verkhneterskiy \\
\hline Amaranthus albus & Tsentralno-Elbrusskiy & Malkinskiy & Kabardinskiy & Verkhneterskiy \\
\hline
\end{tabular}

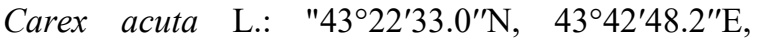
Cherekskiy district, surroundings of the Aushiger village, wet stream bank, near the thermal spring, $539 \mathrm{~m}$ above sea level, 9.VI 2009, N.L. Tsepkova". Herbaceous perennial light-requiring plant, usually growing on the banks of water bodies, in low-lying swamps and in roadside ditches [11]. A.I. Galushko [12] indicated this species for the Western Ciscaucasia and Western Caucasus. T.V. Egorova [13] indicated the species for the Western Ciscaucasia, Western and Eastern Caucasus, Transcaucasia, and Talysh. According to the herbarium label, the new location of Carex acuta belongs to the Balkarskiy floristic region [7] or Malkinskiy floristic region [8]. 


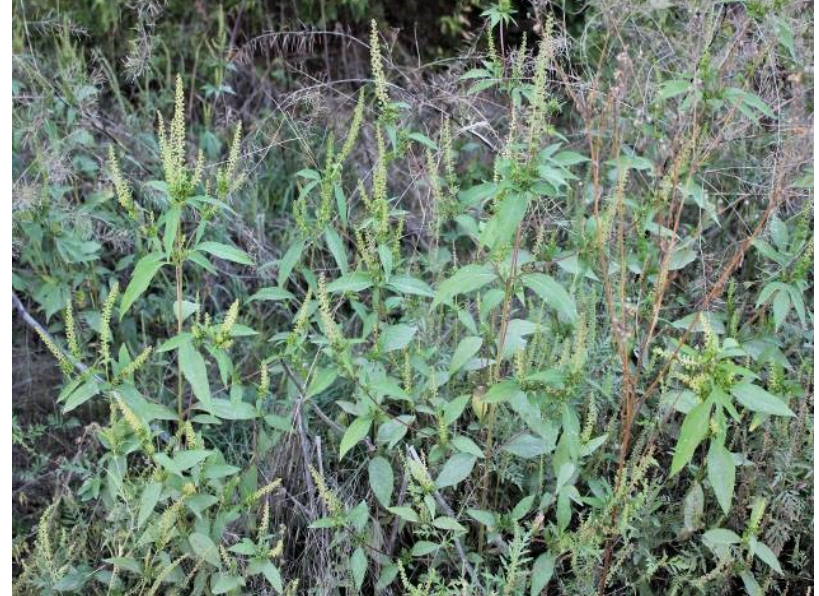

Fig. 3. Ambrosia psilostachya in the Nalchik city

Cleistogenes squarrosa (Trin. ex Ledeb.) Keng: $" 43^{\circ} 26^{\prime} 42.5^{\prime \prime} \mathrm{N}, 42^{\circ} 59^{\prime} 55.6^{\prime \prime} \mathrm{E}$, Elbrusskiy district, four kilometers east of Tyrnyauz city, tailings storage facility of the Tyrnyauz tungsten-molybdenum combine, $1600 \mathrm{~m}$ above sea level, $20 \mathrm{~V}$ 2005, N.L. Tsepkova, N.N. Tsvelev". - Perennial cereal, usually growing on sands, pebbles, rocky slopes and rocks, and in steppes with sandy and sub-sandy soils; up to the middle mountain belt [14]. N.N. Tsvelev [14, 15] indicated Cleistogenes squarrosa for the Eastern Ciscaucasia and Eastern Caucasus. A.I. Galushko [12] indicated this species for the Eastern Caucasus. According to the herbarium label, the new location belongs to the Tsentralno-Elbrusskiy floristic region [7] or Malkinskiy floristic region [8].

Echinocystis lobata (Michx.) Torr. \& A. Gray (Figure 4): "43ำ $16^{\prime} 49.5^{\prime \prime} \mathrm{N} 44^{\circ} 00^{\prime} 32.7^{\prime \prime} \mathrm{E}$, Leskenskiy district, surroundings of the Urukh village, shrubs along the road, $445 \mathrm{~m}$ above sea level, 26 VII 2018, N.L. Tsepkova". - North American annual light-requiring climbing plant, relatively cold-resistant. The species is widely introduced in Europe, Mediterranean, and Asia. Weed plant growing in localities, along roads, among floodplain shrubs. The species is capable of active renewal in invasion territories. It can occupy large areas in floodplains and along roads. N.N. Imkhanitskaya [16] indicated Echinocystis lobata for the Western Ciscaucasia, Western Caucasus, Eastern, and Central Transcaucasia, and also also for the Central Caucasus in surroundings of the Vladikavkaz city (left bank of the Terek river, right bank of the Ursdon river). Location of the species belongs to the Tersko-Sunzhenskiy floristic region [7] or Verkhneterskiy floristic region [8].

Genista angustifolia Schischk.: "4347'22.0" $\mathrm{N}$ $42^{\circ} 56^{\prime} 44.0^{\prime \prime} \mathrm{E}$, Zolskiy district, surroundings of the Kichmalka village, dry grassy slope of the southern exposure, $998 \mathrm{~m}$ above sea level 9 VIII 2012, N.L. Tsepkova". - Perennial shrub, usually growing on the on rocky slopes, limestone rocks. The species is endemic the western part of the North Caucasus A.I. Galushko [17] indicated this species for the Western Transcaucasia and Western Caucasus. A.A. Grossheim [10] indicated it on the limestones of the middle belt of the Western Caucasus. According to the herbarium label, the new location of Genista angustifolia belongs to the
Tsentralno-Elbrusskiy floristic region [7] or Malkinskiy floristic region [8].



Fig. 4. Echinocystis lobata in the surroundings of the Urukh village (Leskenskiy district)

Bidens frondosa L. (Figure 5): $43^{\circ} 14^{\prime} 00.8^{\prime \prime} \mathrm{N}$, $43^{\circ} 32^{\prime} 21.7^{\prime \prime} \mathrm{E}$, Cherekskiy district, shore of the Nizhneye Goluboye lake (Tserik-Kol lake), ruderal plant communities on construction sites, $800 \mathrm{~m}$ above sea level, 27 VIII 2019, V.A. Chadaeva, N.L. Tsepkova". North American herbaceous annual plant with a wide range of environmental conditions suitable for growing. The species withstands environmental pollution, dust, and darkening under the forest canopy. The invasive range of Bidens frondosa covers Europe, China, Korea, Morocco, and New Zealand. A.I. Galushko [12, 17, 18] and S.H. Shkhagapsoev [5] did not indicate the species for the North Caucasus. Yu.L. Menitskiy [20] indicated it as the alien weed of the Western Caucasus, Northwestern and Western Transcaucasia. Location of Bidens frondosa belongs to the Balkarskiy floristic region [7] or Malkinskiy floristic region [8].

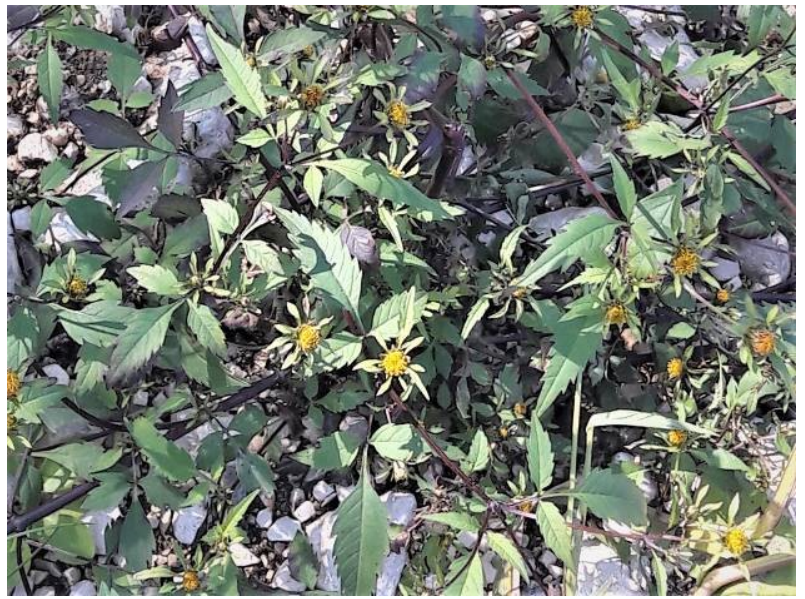

Fig. 5. Bidens frondosa in Cherekskiy district

Mercurialis annua L. (Figure 6): "4329'40.9"N, $43^{\circ} 35^{\prime} 29.9^{\prime \prime} \mathrm{E}$, Nalchik city, ruderal plant community on the roadside, $510 \mathrm{~m}$ above sea level, 10 VIII 2002, N.L. Tsepkova, V.A. Chadaeva, E.I. Stepanyan". Herbaceous annual plant, usually growing in the garbage places, in the fields. The plant is very poisonous. A.I. Galushko [17] indicated this species for the Western 
Caucasus. D.V. Geltman [19] indicated it for the Western and Northwestern Transcaucasia. According to the herbarium label, the new location of Mercurialis annua belongs to the Tsentralno-Elbrusskiy floristic region [7] or Malkinskiy floristic region [8].



Fig. 6. Mercurialis annua in Nalchik

Phlomis majkopensis (Novopokr.) Grossh. (Figure 7): "4332'09.2"N, 44²1'55.6"E, Terskiy district, undisturbed steppe, $312 \mathrm{~m}$ above sea level, $28 \mathrm{~V}$ 2021, N.L. Tsepkova, E.I. Stepanyan". - Rare herbaceous perennial plant, usually growing on dry slopes, in steppes, in bushes and forest clearings on lowlands and in the lower belt [17]. A.I. Galushko [18] indicated this species for the Western Caucasus and Western Ciscaucasia. A.A. Grossheim [10] also indicated it in steppes and forest clearings of the lower belt in the Western Caucasus and Western Ciscaucasia. Location of the Phlomis majkopensis belongs to the TerskoSunzhenskiy floristic region [7] or Verkhneterskiy floristic region [8].

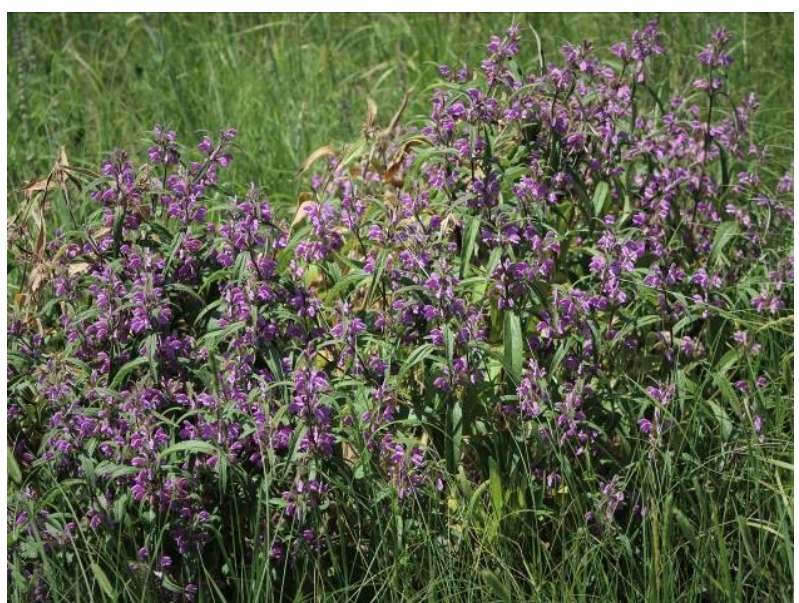

Fig. 7. Phlomis majkopensis in Terskiy district

\subsection{New locations of the species in the Kabardino-Balkar Republic}

Carex flacca subsp. erythrostachys (Hoppe) Holub: "42 $59^{\prime} 04.4^{\prime \prime} \mathrm{N}, \quad 43^{\circ} 19^{\prime} 36.7^{\prime \prime} \mathrm{E}$, Cherekskiy district, Kabardino-Balkaria High Mountain State Reserve, Ushtulu tract, $1852 \mathrm{~m}$ above sea level, $20 \mathrm{~V}$ 2010, N.L.
Tsepkova, E.I. Stepanyan". - Herbaceous perennial plant, usually growing in mountain forests, shrubs, on dry slopes [13]. In regional literary sources [5, 12, etc.], this species is indicated as Carex cuspidata Host. A.I. Galushko [12] indicated it for the Western and Eastern Caucasus, Western Ciscaucasia, and Central Caucasus (Leskenskiy and Kislovodskiy floristic regions). T.V. Egorova [13] indicated the species for the Western and Eastern Caucasus, Western Ciscaucasia, Western, Central and Eastern Transcaucasia, Talysh, and also for the Central Caucasus without precise georeferencing. S.Kh Shkhagapsoev [5] indicated Carex cuspidata for the Kabardino-Balkar Republic also without precise georeferencing and confirmation by herbarium material. According to the herbarium label, the new location belongs to the Balkarskiy floristic region [7] or Malkinskiy floristic region [8].

Carex elongata L.: "43⒋ $41^{\prime} 32.2^{\prime \prime} \mathrm{N} \quad 42^{\circ} 50^{\prime} 52.9^{\prime \prime} \mathrm{E}$, Zolskiy district, surroundings of the Gedmishh waterfall, 1393 м $\mathrm{m}$ above sea level, 25 VIII 2013, N.L. Tsepkova". - Herbaceous perennial plant usually growing in grass-sedge, less often moss swamps, as well as in swampy forests, in ravines and on swampy banks of water bodies [13]. A.I. Galushko [12] indicated the species for the Western Caucasus, and Central Caucasus (Balkarskiy and Osetinskiy floristic regions). T.V. Egorova [13] indicated the species for the Western Caucasus, Western Transcaucasia (partially), and also for the Central Caucasus (Verkhneterskiy floristic region). According to the herbarium label, the new location of Carex elongata belongs to the TsentralnoElbrusskiy floristic region [7] or Malkinskiy floristic region [8]

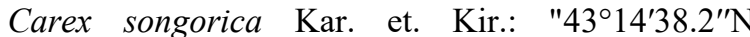
$43^{\circ} 40^{\prime} 54.3^{\prime \prime} \mathrm{E}$, Cherekskiy district, Kabardino-Balkaria High Mountain State Reserve, upper reaches of the Sukan gorge, left bank of the Psygansu river, $771 \mathrm{~m}$ above sea level, 20 VII 2012, N.L. Tsepkova". Herbaceous perennial plant usually growing on damp and marshy meadows, saline meadows, small grassy swamps, along the banks of rivers and lakes, on pebbles from plains to medium or, less often, upper mountain belts [13]. A.I. Galushko [12] indicated the species for the Eastern Caucasus, and Central Caucasus (Verkhnesunzhenskiy and Osetinskiy floristic regions). T.V. Egorova [13] indicated the species for the Eastern Caucasus, South Transcaucasia, and also for the Central Caucasus (Verkhneterskiy floristic region). According to the herbarium label, the new location of Carex elongata belongs to the Balkarskiy floristic region [7] or Malkinskiy floristic region [8].

Acer negundo L. (Figure 8): "433 $37^{\prime} 03.4^{\prime \prime} \mathrm{N}$, $44^{\circ} 05^{\prime} 39.5^{\prime \prime} \mathrm{E}$, Terskiy district, surroundings of the Dzhulat village, in the forest on the banks of the Terek river, $193 \mathrm{~m}$ above sea level, 29 IV 2021, V.A. Chadaeva". - North American deciduous tree that prefers fertile, well-moistened, drained soils and withstands long-term shading. The species is widespread in Europe, less common in Asian countries. Resistant to frost and drought, tolerant to air pollution. 




Fig. 8. Acer negundo in Terskiy district

The species quickly spreads on the territory, preventing the renewal of native forest-forming species. Acer negundo pollen can cause an allergic reaction. A.I. Galushko [12, 17, 18] did not indicate the species for the North Caucasus. S.H. Shkhagapsoev [5] indicated it as an ornamental species in urban landscaping, as well as in the forests of the Kabardino-Balkar Republic (without georeferencing). Location of the species belongs to the Kabardinskiy floristic region [7] or Malkinskiy floristic region [8].

Elsholtzia ciliata (Thunb.) Hyl. (Figure 9): "1) $43^{\circ} 05^{\prime} 07.0^{\prime \prime} \mathrm{N} \quad 43^{\circ} 24^{\prime} 54.8^{\prime \prime} \mathrm{E}$, Cherekskiy district, Kabardino-Balkaria High Mountain State Reserve, surroundings of the the Verkhnyaya Balkariya village, ruderal plant community, $1150 \mathrm{~m}$ above sea level, 28 VII 2021, N.L. Tsepkova; 2) $43^{\circ} 14^{\prime} 00.8^{\prime \prime} \mathrm{N}, 43^{\circ} 32^{\prime} 21.7^{\prime \prime} \mathrm{E}$, Cherekskiy district, shore of the Nizhneye Goluboye lake (Tserik-Kol lake), $800 \mathrm{~m}$ above sea level, 27 VIII 2019, V.A. Chadaeva, N.L. Tsepkova". - Herbaceous annual plant, which is native to China, from where the species penetrated into Afghanistan, Mongolia, Japan, India, Malaysia, Nepal (up to $3400 \mathrm{~m}$ above sea level), Europe, USA [21]. The species prefers lighted habitats, moist soils; it is resistant to drought, pests, and fungal diseases. Elsholtzia ciliata is able to spread rapidly over disturbed territories, disrupting the course of secondary succession. A.I. Galushko [12, 17, 18] did not indicate the species for the North Caucasus. A.A. Grossheim [10] indicated it for weedy places in the lowlands of the Transcaucasia. S.H. Shkhagapsoev [5] indicated it as alien species of weedy places and roadsides in the Kabardino-Balkar Republic (without georeferencing). Locations of the species belong to the Balkarskiy floristic region [7] or Malkinskiy floristic region [8].

Eriophorum latifolium Hoppe (Figure 10): "1) $43^{\circ} 12^{\prime} 22.9^{\prime \prime} \mathrm{N} \quad 42^{\circ} 58^{\prime} 57.8^{\prime \prime} \mathrm{E}$, Chegemskiy district, Kabardino-Balkaria High Mountain State Reserve, Bashil-Auzu Su gorge, floodplain terrace of the left bank of the Bashil river, on the edge of pine undergrowth, $2050 \mathrm{~m}$ above sea level, 8 VII 2020, E.I. Stepanyan; 2) $42^{\circ} 58^{\prime} 27.0^{\prime \prime} \mathrm{N}, \quad 43^{\circ} 20^{\prime} 08.6^{\prime \prime} \mathrm{E}$, Cherekskiy district, Kabardino-Balkaria High Mountain State Reserve, Ushtulu tract, cereal-sedge swamp near the mineral spring, $2028 \mathrm{~m}$ above sea level, 22 VII 2020, E.I.
Stepanyan". - Herbaceous annual plant usually growing on wetlands in the subalpine and alpine belt [22].

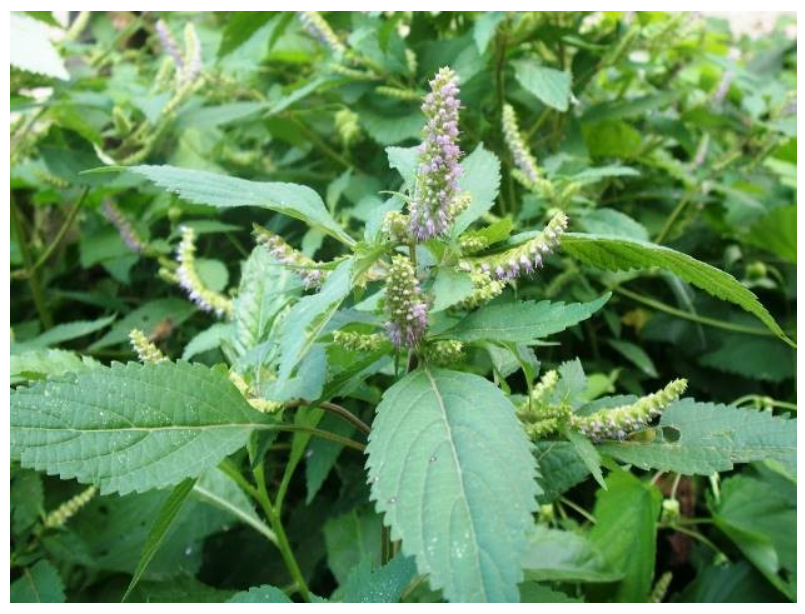

Fig. 9. Elsholtzia ciliata in Cherekskiy district

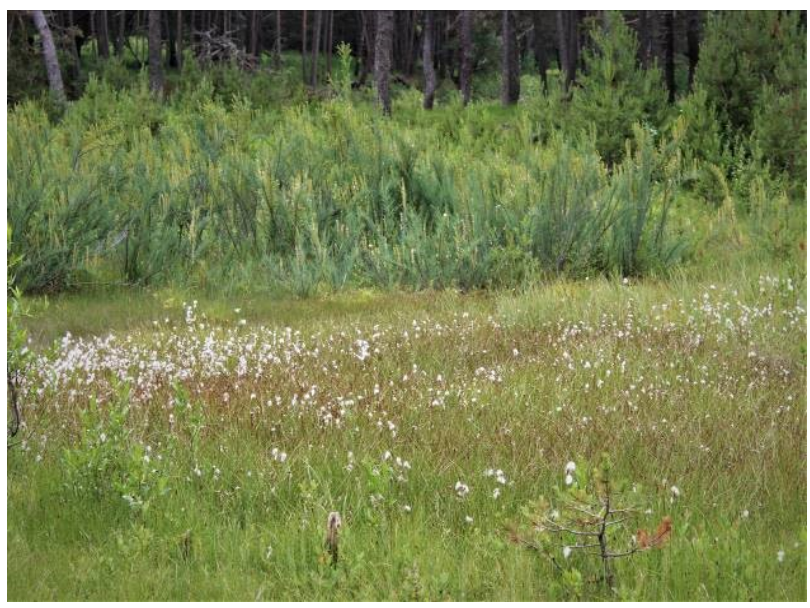

Fig. 10. Eriophorum latifolium in Bashil-Auzu Su gorge

A.I. Galushko [12] indicated Eriophorum latifolium for the Western Caucasus, and Central Caucasus (Osetinskiy floristic region). T.V. Egorova [13] indicated the species for the Western Caucasus and Transcaucasia (partially), and also for the Central Caucasus (Verkhneterskiy floristic region). Both locations of the species belong to the Balkarskiy floristic region [7] or Malkinskiy floristic region [8].

Oenothera biennis L. (Figure 11): "430 $04^{\prime} 40.6^{\prime \prime} \mathrm{N}$ $43^{\circ} 24^{\prime} 02.3^{\prime \prime} \mathrm{E}$, Cherekskiy district, Kabardino-Balkaria High Mountain State Reserve, Ushtulu tract, $1650 \mathrm{~m}$ above sea level, 23 VII 2020, V.A. Chadaeva, E.I. Stepanyan". - Herbaceous biennial plant, which is native to North America, from where the species penetrated into Europe, Japan, China, Australia [21].

The species prefers humid habitats, but often grows in weedy places, roadsides, sands. The ornamental plant used in urban landscaping. With massive distribution, Oenothera biennis displaces native species from plant communities. S.Kh Shkhagapsoev [5] indicated it as the rare alien species on sandy moist soils and roadsides of the Kabardino-Balkar Republic (without georeferencing or confirmation by herbarium material). A.I. Galushko [17] indicated the species for the Western and Eastern Ciscaucasia, Western Caucasus, and Central Caucasus 
(Kislovodskiy, Pyatigorskiy, Leskenskiy, Kabardinskiy, Checheno-Osetinskiy, Tersko-Sunzhenskiy regions). Location of Oenothera biennis belongs to the Balkarskiy floristic region [7] or Malkinskiy floristic region [8].

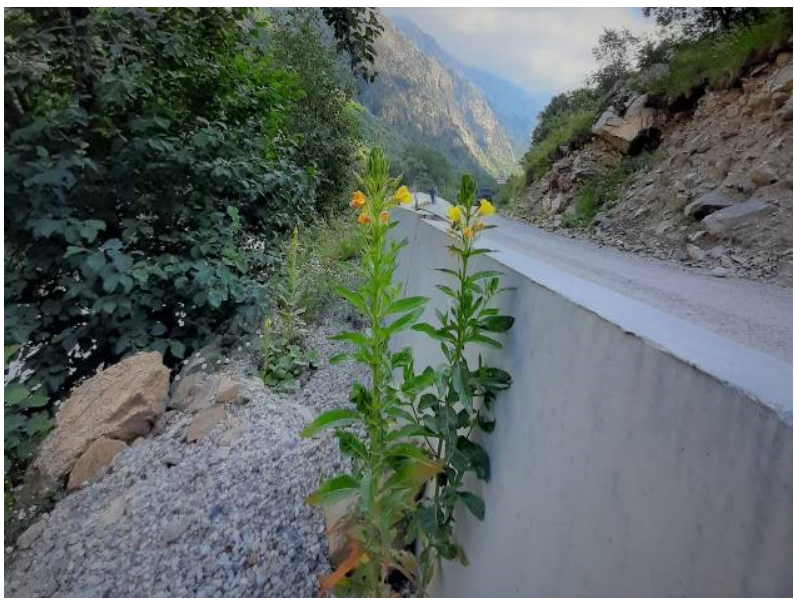

Fig. 11. Oenothera biennis in Cherekskiy district

Glaucium corniculatum (L.) Curtis (Figure 12):

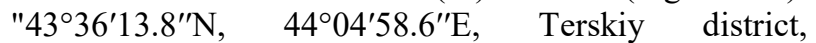
surroundings of the Dzhulat village, undisturbed steppe, $255 \mathrm{~m}$ above sea level, 28 V 2021, E.I. Stepanyan, N.L. Tsepkova". - Herbaceous annual plant growing usually on weedy and stony places, on slopes, and in fields. S.Kh Shkhagapsoev [5] indicated the species on rocky slopes and talus in the Kabardino-Balkar Republic (without georeferencing or confirmation by herbarium material). A.I. Galushko [17] indicated the species for the Eastern Caucasus, and Central Caucasus (Kislovodskiy, Pyatigorskiy, Tsentralno-Elbrusskiy, Leskenskiy, Unalskiy, Checheno-Osetinskiy, Balkarskiy, Osetinskiy regions). D.D. Mikheyev [23] indicated it for the Western and Eastern Ciscaucasia, Western and Eastern Caucasus, Transcaucasia, Talysh, and also for the Central Caucasus (without georeferencing). Location of Glaucium corniculatum belongs to the TerskoSunzhenskiy floristic region [7] or Verkhneterskiy floristic region [8].

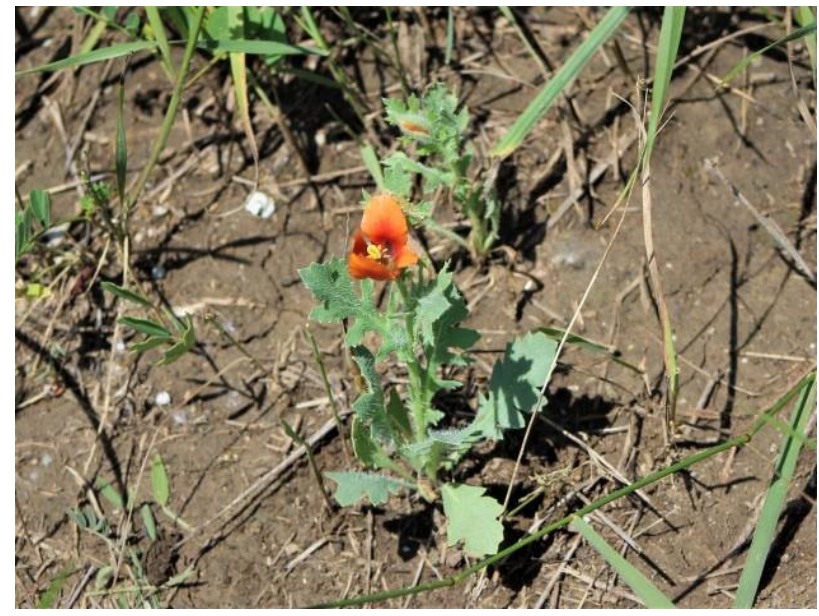

Fig. 12. Glaucium corniculatum in Terskiy district
Sigesbeckia orientalis L. (Figure 13): "1) $43^{\circ} 29^{\prime} 02.7^{\prime \prime} \mathrm{N}, 43^{\circ} 35^{\prime} 51.5^{\prime \prime} \mathrm{E}$, Nalchik city, ruderal plant community, $512 \mathrm{~m}$ above sea level, 1 VII 2018, N.L. Tsepkova; 2) $43^{\circ} 14^{\prime} 00.8^{\prime \prime} \mathrm{N}, 43^{\circ} 32^{\prime} 21.7^{\prime \prime} \mathrm{E}$, Cherekskiy district, the shore of the Nizhneye Goluboye lake (Tserik-Kol lake), $800 \mathrm{~m}$ above sea level, 27 VIII 2019, V.A. Chadaeva, N.L. Tsepkova". - Herbaceous annual plant growing usually in weedy places, wastelands, along roads, in gardens, parks, on forest edges, and on the banks of water bodies. The plant prefers moist habitats, and it is thermophilic. The origin of Sigesbeckia orientalis is associated with the subtropics and tropics of the Old World. The species is widely distributed in North America, China, the Middle East, and Central Asia.

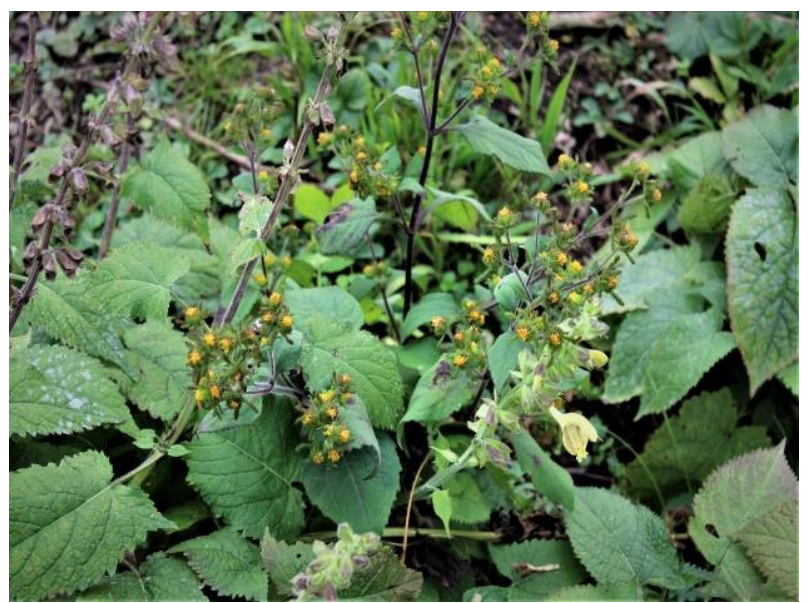

Fig. 13. Sigesbeckia orientalis in Cherekskiy district

S.Kh Shkhagapsoev [5] indicated the species as the alien plant of ruderal places, gardens, forest edges in the Kabardino-Balkar Republic (without georeferencing). A.I. Galushko [18] indicated the species for the Northwestern Transcaucasia, Western Transcaucasia, Eastern Caucasus, and Central Caucasus (Kislovodskiy, Pyatigorskiy, Leskenskiy regions). Yu.L. Menitskiy [20] indicated Sigesbeckia orientalis as the alien weed for the Western and Eastern Ciscaucasia, Western, Eastern, Central, and Northwestern Transcaucasia, Western and Eastern Caucasus, as well as Central Caucasus (Verkhneterskiy and Malkinskiy floristic regions). Locations of the species belong to the Balkarskiy floristic region [7] or Malkinskiy floristic region [8].

Amaranthus albus L. (Figure 14): "43⒉ $29^{\prime} 04.2^{\prime \prime} \mathrm{N}$, $43^{\circ} 38^{\prime} 12.9^{\prime \prime} \mathrm{E}$, Nalchik city, ruderal plant community on sandy soil, $500 \mathrm{~m}$ above sea level, 25 VII 2020, V.A. Chadaeva". - North American herbaceous annual plant usually growing in weedy places, along the railway and roads, or in vegetable gardens on fertile soils. Droughtresistant, thermophilic species. The species is widely introduced in Europe, Asia, North Africa. Amaranthus albus quickly disperses through numerous small seeds, carried by wind and water, with the ground. It clogs agricultural crops, vegetable gardens, and orchards. 


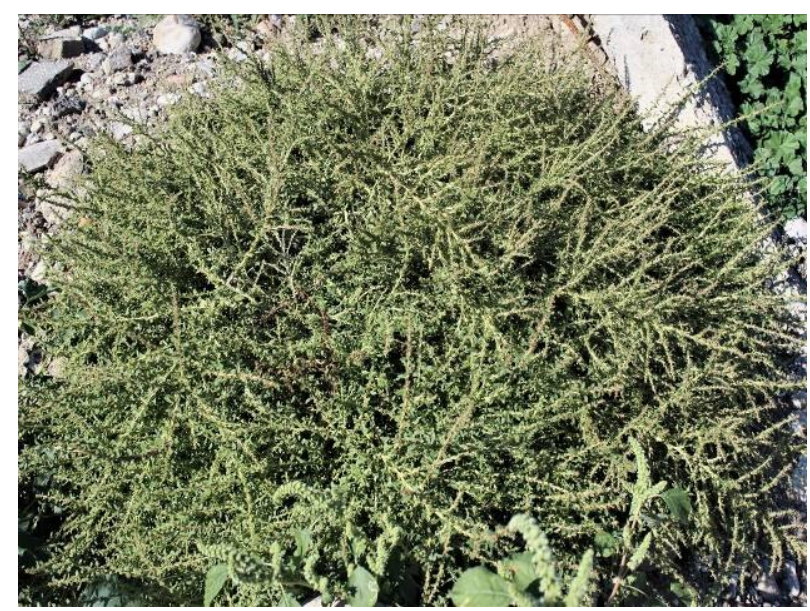

Fig. 14. Amaranthus albus in the Nalchik city

S.Kh Shkhagapsoev [5] did not indicate the species for the Kabardino-Balkar Republic. A.I. Galushko [18] indicated the species for the Western and Eastern Caucasus, Western Ciscaucasia, and Central Caucasus (Kabardinskiy region). Yu.L. Menitskiy [20] indicated Amaranthus albus as the alien weed for the Western and Eastern Caucasus, Western Ciscaucasia, Western, Eastern, Central, and Northwestern Transcaucasia, Talysh, as well as Central Caucasus (Verkhneterskiy floristic region). Location of the species belongs to the Tsentralno-Elbrusskiy floristic region [7] or Malkinskiy floristic region [8].

\section{Conclusions}

We identified nine new species of the natural flora of the Kabardino-Balkar Republic (Central Caucasus) as a result of inventory studies in the herbarium collection of the Tembotov Institute of Ecology of Mountain Territories of Russian Academy of Science and expeditionary studies in 2020-2021. Species new to the regional flora were Carex acuta, Genista angustifolia, Amorpha fruticosa, Ambrosia psilostachya, Mercurialis annua, Echinocystis lobata, Phlomis majkopensis, Cleistogenes squarrosa, Bidens frondosa. Among them, Genista angustifolia, Cleistogenes squarrosa, Bidens frondosa were collected during the researches of mountain areas. Carex acuta, Amorpha fruticosa, Phlomis majkopensis, Echinocystis lobata were collected during studies of lowland and foothill territories, the main of which is agricultural lands now. Ambrosia psilostachya, Mercurialis annua were found in the ruderal plant communities of Nalchik city. Native rare species of the natural flora of the Kabardino-Balkar Republic are Carex acuta, Genista angustifolia, Phlomis majkopensis, and, most likely Cleistogenes squarrosa. We found the latter within the technogenic landscape (the tailings storage facility of the Tyrnyauz tungstenmolybdenum combine) and did not mark it anywhere else in the region. Ambrosia psilostachya, Mercurialis annua, Amorpha fruticosa, and Echinocystis lobata are alien species, which probably invaded the natural and ruderal plant communities of the Kabardino-Balkar
Republic relatively recently. These alien plants can cause great damage to the natural meadow and forest ecosystems and can disrupt the course of secondary successions. Therefore, it is necessary to control their number and distribution in the region.

In addition, we established new localities of ten plant species, the distribution of which was previously indicated for other floristic regions of the Central Caucasus. New locations of the native species Carex flacca subsp. erythrostachys, C. songorica, Eriophorum latifolium and alien species Oenothera biennis, Elsholtzia ciliata, Sigesbeckia orientalis, Bidens frondosa were identified for the Balkarskiy floristic region. Native species Carex elongata and alien species Amaranthus albus were revealed for the TsentralnoElbrusskiy floristic region. Acer negundo were revealed for the Kabardinskiy floristic regions. We also found Glaucium corniculatum in the Tursko-Sunzhensky floristic region.

In the new edition of the regional Red Book, we propose to include three species new to the native flora of the Kabardino-Balkar Republic with the assignment of the rarity status category "Rare species". They are Cleistogenes squarrosa, Phlomis majkopensis, and Genista angustifolia.

The studies were carried out as part of state assignment no. 075-00347-19-00 on the topic "Patterns of the Spatiotemporal Dynamics of Meadow and Forest Ecosystems in Mountainous Areas (Russian Western and Central Caucasus)."

\section{References}

1. C.I. Orozco, Á.J. Pérez, K. Romoleroux, J.M. Aldana, Phytotaxa 311(3), 263-269 (2017)

2. C.H. Stirton, A.M. Muasya, Kew Bull. 72, 50 (2017)

3. F. Conti, R. Pennesi, D. Uzunov, L. Bracchetti, F. Bartolucci, Phytotaxa 336(1), 69-81 (2018)

4. B. Mani, S. Thomas, S.J. Britto, Phytotaxa 334(3), 233-240 (2018)

5. S.Kh. Shkhagapsoev, Rastitelnyy pokrov KabardinoBalkarii (Nalchik, Tetragraf, 2015)

6. A.K. Tembotov, E.A. Shebzukhova, F.A. Tembotova, A.A. Tembotov, I.L. Vorokova, Problemy ekologii gornykh territoriy (Maykop, 2001)

7. A.I. Galushko, Florogeneticheskiye rayony Tsentralnogo Kavkaza (Stavropol, 1976)

8. Yu.L. Menitsky, Bot. zhurn. 76(11), 1513-1521 (1991)

9. TPL (The Plant List), Available at http://www.theplantlist.org (accessed May 2021)

10. A.A. Grossheim, Opredelitel rasteniy Kavkaza (Moscow, 1978)

11. A.S. Zernov, Yu.E. Alekseev, V.G. Onipchenko, A Guide to the vascular plants of KarachaevoCherkessia (Moscow, 2015) 
12. A.I. Galushko, Flora Severnogo Kavkaza. Opredelitel, 1 (Rostov-on-Don, 1978)

13. T.V. Egorova, Caucasian flora conspectus 2, 179244 (2006)

14. N.N. Tzvelev, N.S. Probatova, Grasses of Russia (Moscow, 2005)

15. N.N. Tzvelev, Caucasian flora conspectus 2, 243378 (2006)

16. N.N. Imkhanitskaya, Caucasian flora conspectus 3(2), 362-368 (2012)

17. A.I. Galushko, Flora Severnogo Kavkaza. Opredelitel, 2 (Rostov-on-Don, 1980)

18. A.I. Galushko, Flora Severnogo Kavkaza. Opredelitel, 3 (Rostov-on-Don, 1980)

19. D.V. Geltman, Caucasian flora conspectus 3(2), 494-512 (2012)

20. Yu.L. Menitskiy, Caucasian flora conspectus 3(1), 163-386 (2006)

21. Yu.K. Vinogradova, S.R. Mayorov, L.V. Khorun, The Black Book of Flora of Central Russia (Moscow, GEOS, 2010)

22. A.S. Zernov, V.G. Onipchenko, Vascular plants of the Karachay-Cherkess Republic (Abstract of flora) (Moscow, MAKS Press, 2011)

23. D.D. Mikheyev, Caucasian flora conspectus 3(2), 109-119 (2012) 